Vol. 6, No. 1, 2021, pp. 83-88

Contents lists available at \ournal IICET

JRTI (Jurnal Riset Tindakan Indonesia)

ISSN: 2502-079X (Print) ISSN: 2503-1619 (Electronic)

\title{
Kebijakan publik: konsep pelaksanaan
}

\author{
Desrinelti Desrinelti $^{\left.1^{*}\right)}$, Maghfirah Afifah ${ }^{1}$, Nurhizrah Gistituati $^{1}$ \\ ${ }^{1}$ Universitas Negeri Padang, Indonesia
}

\begin{tabular}{l} 
Article Info \\
\hline Article history: \\
Received Apr $13^{\text {th }}, 2021$ \\
Revised May $23^{\text {rd }}, 2021$ \\
Accepted Jun $12^{\text {th }}, 2021$ \\
\hline
\end{tabular}

\section{Keyword:}

Kebijakan

Publik

Konsep

Pelaksanaanya

\begin{abstract}
Sebuah negara harus melakukan proses pembangunan agar meningkatnya kesejahteraan masyarakat. Proses pembangunan tersebut dapat dituangkan dalam kebijakan yang bersifat terikat dan memaksa. Agar kebijakan tersebut dapat menunjang keberhasilan pembangunan maka diperlukan pemahaman kebijakan publik lebih mendalam. Tujuan penulisan artikel ini adalah mengkaji konsep dasar kebijakan publik yang dapat dijadikan landasan dalam melakukan analisis dan evaluasi pelaksanaan kebijakan publik. Metodologi penulisan ini menggunakan metodologi studi kepustakaan. Penulisan artikel ini dilakukan dengan mengkaji sebanyak 23 artikel nasional yang berhubungan dengan kebijakan publik yang terdapat pada database google scholar. Hasil studi kepustakaan menyatakan bahwa pelaksanaan kebijakan merupakan kegiatan, program dan aktivitas dalam penerapan keputusan kebijakan dalam rangka mencapai tujuan yang ditetapkan pada keputusan kebijakan. Pelaksanaan kebijakan dipengaruhi oleh empat aspek yaitu disposisi, sumber daya, komunikasi dan struktur birokrasi. Selain itu terdapat dimensi yang ada dalam proses pelaksanaan kebijakan yaitu efisiensi, efektivitas, keadilan, akuntabilitas, transparansi dan konsistensi. Untuk mengetahui keberhasilan pelaksanaan kebijakan maka ada tiga tahapan dalam penilaian pelaksanaan kebijakan yaitu penilaian ex-ante, on-going dan ex-post. .
\end{abstract}

(C) 2021 The Authors. Published by IICET.

This is an open access article under the CC BY-NC-SA license

(https://creativecommons.org/licenses/by-nc-sa/4.0)

\section{Corresponding Author:}

Desrinelti Desrinelti,

Universitas Negeri Padang

Email: desrinelti@gmail.com

\section{Pendahuluan}

Sebuah negara harus memastikan proses pembangunan bangsa dapat terlaksana dengan baik (Retnaningsih, 2015). Pembangunan merupakan sebuah kegiatan yang dilakukan secara bersamaan, konsisten dan berkesinambungan yang dilakukan oleh berbagai pihak seperti pemerintah, swasta dan masyarakat dengan tujuan untuk mencapai kesejahteraan bersama baik dari aspek materil maupun aspek spritural (Wirawan and Nurpratiwi, 2015). Pembangunan sangat berhubungan erat dengan kebijakan. Sebuah pembangunan dilandasi oleh kebijakan yang dijadikan sebagai pedoman dalam proses pelaksanaannya. Didalam kebijakan tersebut terdapat arahan serta larangan yang dapat menjamin terlaksananya proses pembangunan yang terarah dan sesuai dengan tujuan yang telah disepakati.

Kebijakan yang berhubungan dengan publik disebut dengan kebijakan publik (Sirajuddin, 2016). Kebijakan publik lahir dari adanya kebutuhan dan permasalahan yang dihadapi oleh masyarakat. Pembuat kebijakan publik disebut dengan stakeholder. Stake holder dalam pembuatakan kebijakan publik adalah pemerintah dengan tujuan untuk memenuhi kebutuhan masyarakat dengan azaz kepentingan masyarakat. Kebijakan publik dimaknai sebagai sebuah hubungan dalam mencapai sasaran dan tujuan dari hasil akhir kegiatan yang di 
selenggarakan oleh pemerintah (Coryanata, 2011). Kekurangan dari sebuah kebijakan publik dapat diketahui setelah kebijakan tersebut terlaksana sedangkan keberhasilan dari sebiuah kebijakan publik tersebut dapat dilihat dari dampak yang dihasilkan setelah pelaksanaan kebijakan.

Pelaksanaan kebijakan dapat dimaknai sebagai sebuah proses dalam mengimplementasikan sebuah kebijakan. Pelaksanaan kebijakan memiliki luaran berupa aksi, aktivitas, mekanisme dan tindakan yang di bingkai dalam sebuah sistem (Ramdhani and Ramdhani, 2017). Pelaksanaan kebijakan dapat juga diartikan sebagai sebuah aktivitas yang terencana dan dilakukan dengan sunggih-sungguh dengan dilandasi denagn acuan norma yang disesuaikan untuk pencapaian tujuan pembelajaran yang disepakati (Afandi and Warijo, 2015).

Proses pelaksanaan kebijakan tidak hanya semata dilaksanakan oleh lembaga adminstrasi yang telah ditetapkan. Namun juga pelaksanaan kebijakan publik juga ditentukan oleh keterlibatan masyarakat berupa kekuataan sosial, ekonomi dan politik serta keterlibatan berbagai pihak (Bakry, 2010; Juliastuti, 2013). Pelaksanaan kebijakan yang dilaksanakan dengan tepat sasaran, proa katif dan berdaya guna akan menghasilkan luaran kebijakan yang dapat memecahkan berbagai permasalahan (Suryono, 2014; Sururi, 2016). Semakin kompleks permasalahan yang dihadapi maka diperlukan proses analisis yang lebih dalam maka diperlukan teori-teori dan modal yang luas agar dapat memahami proses pelakanaan kebijakan tersebut. Proses analisis kebijakan perlu dilakukan agar dapat berpengaruh terhadap kebijakan yang dilahirkan (Alam, 2012). Pengkajian pelaksanaan kebijakan dilaksanakan dengan tujuan agar kebijakan yang dilahirkan bersifat problem solving dan mengutamakan kepentingan masyarakat (Aziz et al, 2020). Hal tersebut lah yang melatarbelakangi penulisan artikel ini agar kebijakan publik yang dilahirkan dapat mencapai tujuan yang dilandaskan kepentingan masyarakat.

Artikel ini bertujuan untuk mengkaji konsep dasar kebijakan publik yang dapat dijadikan landasan dalam melakukan analisis dan evaluasi pelaksanaan kebijakan publik.

\section{Metode}

Metodologi penulisan ini menggunakan metodologi studi kepustakaan. Penulisan artikel ini dilakukan dengan mengkaji sebanyak 23 artikel nasional yang berhubungan dengan kebijakan publik yang terdapat pada database google scholar.

\section{Hasil dan Pembahasan}

\section{Kebijakan Publik}

Kebijakan merupakan sebuah rangkaian aktivitas, aksi, sikap, rencana progaram dan kuputusan yang dilakan oleh para aktor (pihak terkait) sebagai upaya dalam memecahkan permasalahan yang dihadapi (Herdiana, 2018). Sebuah kebijakan merupakan hal yang penting dalam mencapai suatu tujuan pada organisasi. Kebijakan terdiri dari dua aspek yaitu (a) Kebijakan merupakan sebuah bentuk respon mengenai kejadian yang terjadi untuk menghasilkan harmonisasi dari pihak yang berkepentingan, menciptakan intensif atas prilaku pihak yang mendapatkan perlakuan yang tidak rasional atas kerja bersama, (b) Kebijakan merupakan sebuah praktik sosial. Kebijakan bukan lah hal yang bersifat tunggal maupun terisolir (Iskandar, 2012). Artinya bahwa kebijkan merupakan suat hal yang di hasilkan oleh pembuat kebijakan (pemerintah) sebagai bentuk perumusan yang didasari oleh peristiwa yang terjadi di masyarakat. Peristiwa tersebut dilahirkan dari proses kehidupan bermasyarakat yang bukan bersifat asing, terisolasi dan berdiri sendiri bagi masyarakat.

Dari pernyataan tersebut dapat diartikan bahwa kebijakan merupakan usaha dalam mencapai tujuan yang telah ditetapkan dan juga sebagai bentuk dalam memecahkan permasalahan dengan menggunakan fasilitas tertentu dan dalam waktu yang telah ditetapkan. Sebuah kebijakan bersifat mendasar. Hal ini dikarenakaan kebijakan dapat dijadikan pedomaan dalam mencapai tujuan yang telah ditetapkan bersama.

Kebijakan dapat berasal dari suatu individu maupun kelompok yang melaksanakan serangkaian tindakan/ aktivitas/ maupun program dalam mencapai tujuan tertentu. Kebijakan juga diartikan sebagai sebuah sistem yang terdiri dari input, proses dan output (Hanafi and Ma`sum, 2015). Input kebijakan adalah agenda pemerintah maupun isu-isu yang terjadi. Proses kebijakaan terdiri dari proses perumusan kebijakan dan pelaksanaan kebijakan. Proses perumusan dan pelaksanaan kebijakan dilaksanakan oleh kelompok penekan atau yang dikenal dengan istilah elit politik. Output sebuah kebijakan merupakan kinerja kebijakan. Oleh sebab itu sebuah kebijakan tidak bersifat permanen. Kebijakan dapat dilahirkan dalam rentang waktu yang tidak dapat ditentukan serta sebagai bentuk pemecahan permasalahan atas kejadian-kejadian yang ada pada masyarakat. 
Kebijkan publik juga dapat diartikan sebagai : 1) Tindakan yang bertujuan pada proses pencapai tujuan dari pada tindakan yang dilaksankan secara kebetulan; 2) Tindakan yang saling berhubungan dan terdapat pola-pola yang menuju kepada pencapaian tujuan yang dilaksanakan oleh pemerintah dan bukan oleh keputusan diri sendiri; 3) Kegiatan yang dilakukan dengan sadar, sengaja, dan terarah yang dilakukan oleh pemerintah dalam suatu bidang; 4) Pedoman oleh pemerintah dalam mengatasi permasalahan tertentu dan sebuah keputusan untuk tidak melakukan tindakan sesuatu (Jann and Wegrich, 2007).

Maka dari pengertian ini dapat diartikan bahwa kebijakan publik merupakan kegiatan sadar, sengaja, dan terarah yang dilakukan oleh pemerintah dalam mencapai tujuan tertentu.

Sebuah kebijakan harus dituangkan kedalam peraturan perundangan-perundangan (Safira, 2018). Hal ini dikarenakan dalam peraturan perundang-undangan terdapat sistem yang bersifat memaksa dan mengikat. Sehingga dengan dimasukannya kedalam sistem perundang-undangan, setiap kebijakan yang dihasilkan harus dilaksankan oleh setiap orang tanpa terkecuali. Oleh sebab itu sebelum kebijakan tersebut diterapkan perlunya proses legtimasi oleh lembaga yang memiliki wewenang.

Kebijakan publik yang menghasilkan peraturan perundang-undangan merupakan bagian dari komuditas politik yang berkaitan dengan kepentingan publik (Alam, 2012). Namun kebijakan publik dapat diperbaiki apabila terjadi dinamika yang berdampak kepada kebijakan tersebut. Oleh sebab itu kebijakan publik bersifat fleksibel yang bisai diperbaiki dan di sesuaikan berdasarkan perkembangan pembangunan. Proses perbaikan dan penyesuaian tersebut dipengaruhi oleh penilaian yang dilakukan masyarakat.

Kebijakan publik tidak akan terlaksana apabila tidak ada proses pelaksanaan kebijakan publik tersebut. Pelaksanaan kebijakan publik merupakan rangkaian tindakan dalam merumuskan dan melaksanakan kebijakan. Proses pelaksanaaan kebijakan publik didasari pada mekanisme, sumber daya dan keterkaitan program kebijakan.

Pelaksanaan kebijakan merupakan aktivitas lanjutan dari perumusan dan pengesahan kebijakan (Mutiasari et al, 2016). Maka dapat dimaknai bahwa pelaksanaan kebijakan publik merupakan aktivitas yang dilakukan oleh individu maupun kelompok dalam mencapai suatu tujuan yang didasari oleh kebijakan yang telah disahkan. Dampak dari pelaksanaan kebijakan adalah munculnya konsekuensi dari pelaksanaan kebijakan tersebut. Hasil pelaksanaan kebijakan yang dievaluasi akan mendapatkan hasil yang diharapkan (intended) atau juga hasil yang tidak diharapkan (spillover negative effect). Maka dapat disimpulkan bahwa setiap kebijakan yang ditetapkan akan memiliki dampak.

Pelaksanaan kebijakan terdiri dari tiga unsur utama yaitu: 1) Spesifikasi rincian program. Spesifikasi rincian program berhubunagan dengan dimana dan bagaimana lembaga melaksanakan program dan seperti apa program atau hukum ditafsirkan; 2) Alokasi sumber daya. Berhubungan dengan pembiayaan, personil dan organisasi yaang melaksanakan serta bertanggung jawab atas keterlaksanaan program; 3) Keputusan. Berhubungan dengan ketetapan yang dilaksanakan, (Jann and Wegrich, 2007).

Pelaksanaan kebijakan akan berdampak kepada keberhasilan kebijakan tersebut. Sebuah kebijakan dikatakan berhasil apabila memberikan penagruh positif kepada masyarakat. Artinya bahwa kebijakan mampu mengarahkan masyarakat menjadi lebih terarah dan sesuai dengan keingginan pemerintah. Maka pemerintah memiliki kewajiban dalam mengawasi keterlaksanaan kebijakan melalui perancangan program dan strukturisasi proses pelaksanaan. Maka dapat disimpulkan bahwa pelaksanaan kebijakan merupakan kegiatan, program dan aktivitas dalam penerapan keputusan kebijakan dalam rangka mencapai tujuan yang ditetapkan pada keputusan kebijakan.

\section{Aspek-aspek yang Mempengaruhi Pelaksanaan dan Dimensi Kebijakan Publik}

Pelaksanaan kebijakan merupakan sebuah proses yang bertahap yang dilakukan seteah kebijakan dilahirkan dan sebelum diketahui dampak yang dihasilkan. Pelakasanaan kebijakan publik dipengaruhi oleh beberapa aspek yang saling berkaitan dan mempengaruhi satu dengan yang lainnya. Aspek tersebut adalah :

\section{Struktur Birokrasi / kewenangan}

Kewenanangan diartikan sebagai otoritas maupun legitimasi bagi pihak yang melaksanakan kebijakan yang ditetapkan secara politik. Kewenangan ini berhubungan dengan posisi individu maupun lembaga dalam proses pelaksanaan kebijakan (Suryono, 2014). Kewenangan ini dituangkan dalam fragmentasi organisasi maupu prosedur kerja seperti SOP.

\section{Komunikasi}

Komunikasi merupakan bentuk kegiatan yang dapat membuat individu untuk menginterprestasikan gagasan dan ide melalui sebuah sistem yang dapat berupa signal, simbol, lisan maupun prilaku. Komunikasi sangat berpengaruh terhadap pelaksanaan kebijakan publik (Ruhimat, 2010; Subekti et al, 2017; Syani et al, 2018). 
Komunikasi dapat memberikan dampak yang baik dan buruk tehadap pelaksanaan kebijakan. Apabila sebuah informasi disampaikan secara jelas kepada masyarakat maka akan mengurangi resiko resistensi didalam masyarakat dan justru sebaliknya apabila informasi yang disampaiakan tidak jelas maka memungkinkan terjadinya gejolak dalam kelompok masyarakat tersebut.

\section{Sumber daya}

Sumber daya sangat diperlukan dalam menunjang pelaksanaan kebijakan seperti manusia, materi dan metode pelaksanaan (Kartini, 2017; Fahri, 2017). Proses pelaksanaan kebijakan harus dilakukan dengan cermat dan terarah, apabila dalam pelaksanaan kebijakan kekurangan sumber daya maka kegiatan tersebut tidaka akan terlaksana secara maksimal.

\section{Disposisi atau sikap dari pelaksana}

Disposisi merupakan watak atau tabiat dari pelaksana kebijakan. Watak tersebut dapat berupa kejuruan, displin, kecerdasan dan komitmen. Apabila pelaksanaa kebijakan memiliki disposisi yang baik maka proses pelaksanaan kebijakan akan cendrung optimal dan apabila pelaksana kebijakan memiliki disposisi yang tidak baik maka pelaksaaan kebijakan tidak akan berjalan secara optimal.

Dari penjabaran tersebut dapat diartikan bahwa terdapat 4 aspek yang mepengaruhi pelaksanaan kebijakan yaitu kewenangan, komunikasi, sumber daya dan disposisi yang antar komponen saling berkaitan dan mempengaruhi. Selanjutnya dalam proses pelaksanaan kebijakan terdapat dimensi kebijakan publik yang harus diketahui.

Konsep pelaksanaan kebijakan di Indonesia berlandaskan good governance. Untuk mencapai good governance tersebut perlu diketahui dimensi pencapaian yaitu (Hardiansyah, 2018): 1) Konsistensi. Sebuah kebijakan akan terlaksana dengan baik apabila pelaksanaanya dilakukan secara konsisten yang sesuai dengan norma dan prosedur yang berlaku; 2) Transparansi. Transparansi ada jika terdapat kebebasan akses yang dapat dilakukan oleh publik atau kelompok yang memiliki kepentingan . Transparansi informasi harus bersifat terbuka, mudah diakses, mudah dimengerti, dan tersedia secara memadai; 3) Akuntabilitas. Pelaksanaan sebuah kebijakan harus dapat di pertanggung jawabkan sesuai dengan peraturan perundang-undangan; 4) Keadilan. Keadilan dalam pelaksanaan kebijakan publik dapat berupa tidak membedakan pelayanan terhadap golongan tertentu (tidak besikap deskriminatif); 5) Partisipatif. Partisipatif artinya bawah masyarakat berperan dalam keterlibatanya pada pelaksanaan kebijakan. Selain sebagai penopang pelaksanaan kebijakan, masyarakat juga berperan sebagai sarana untuk evaluasi dan pengontrolan terhadap wawenang pelaksana kebijakan; 6) Efektivitas. Efektivitas berhubungan dengan ketercapaian hasil kebijakan berdasarkan tindakan dan aspek rasionalitas tindakan yang berhubungan dengan layanan atau produk. Sebuah pelaksana kebijakan dikatakan efektif apabila tercapainya sasaran dan tujuan yang telah ditetapkan; 7) Efisiensi. Efisiensi berhubungaan dengan kuantitas pemaksimalan sumber daya seperti pencapaian tujuan, pengunaan manusia, biaya, waktu dan peralatan lainnya. Efisiensi akan berdampak kepada efektivitas pelaksanaan kebijakan.

Dimensi-dimensi inilah yang harus diperhatikan dalam proses pelaksanaan kebijakan agar kebijakan yang ditetapkan dapat mencapai tujuan.

\section{Evaluasi Pelaksanaan Kebijakan Publik}

Keberhasilan pelaksanaan kebijakan publik melibatkan berbagai stakeholder secara partisipatif dan demokratis. Pembuat kebijakan dan stakeholder secara kolaboratif terlibat dalam proses analisis dan pelaksana kebijakan. Maka diperlukan evaluasi sebagai bentuk penilaian akuntabilitas dan kinerja dari kebijakan publik yang dilaksanakan. Ada tiga tahapan bentuk evaluasi pelaksanaan kebijakan publik yaitu:

\section{Evaluasi pada tahapan perencanaan}

Evaluasi pada tahapan perencanaan ini disebut juga dengan ex-ante yang artinya bahwa kebijakan dilaksanakan dengan maksud mimilih alternatif prioritas dari berbagai alternatif yang telah dirumuskan (Kawengian and Rares, 2015). Tujuan evaluasi tahapan ini adalah untuk menghindari penilaian awal yang diberikan kepada kebijakan yang telah ditentukan. Selain itu juga sebagai pemberi informasi tehadap kebijakan yang sedang dilaksanakan. Evaluasi pada tahapan ini juga dapat memberikan pengkajian awal pengaruh terhadap lingkungan.

\section{Evaluasi pada tahap pelaksanaan}

Evaluasi pada tahapan pelaksanaan ini disebut juga dengan on-going. Evaluasi ini bertujuan untuk menentukan kemajuan pelaksanaan yang dibandingkan dari proses awal kegiatan (Prastisha and Triharjanto, 2020). Evaluasi ini bertujuan untuk memastikan bahwa pelaksanaan sesuai dengan perencanaan yang telah ditetapkan. Apabila ada kesalahan yang terjadi pada proses pelaksanaan evaluas maka akan segera diatasi melalui penilaian ongoing ini melalui proses rekomendasi. Selain itu evaluasi on going juga dapat 
memberikan informasi yang berhubungan dengan proses pelaksanaan kebijakan yang sesuai dengan tujuan yang telah ditetapkan.

\section{Evaluasi pada tahap pasca pelaksanaan}

Evaluasi pada tahapan ini disebut juga dengan ex-post. Evaluasi ini bertujuan untuk mengetahui tingkat ketercapaian pelaksanaan kegiatan (Budiani and Suliyati, 2016). Selain itu tahapan ini juga bertujuan untuk penganalisisan tingkat ketercapaian luaran kebijakan. Selain itu pada tahapan ini juga dapat diketahui efektivitas dan efisiensi pelaksanaan kebijakan yang telah dilaksanakan.

Ketiga tahapan evaluasi ini harus dilaksanakan pada proses pelaksanaan kebijakan agar dapat menilai sejauh mana pelaksanaan kebijakan berjalan sesuai dengan rencana yang telah disepakati. Proses penilaian kebijakan yang dilakukan di Indonesia menggunakan gabungan dari ketiga bentuk penilaian. Hal ini dikarenakan objek kebijakan yang luas dan sumber daya yang variatif harus dapat memastikan bahwa kebijakan tersebut harus tepat sasaran dalam memecahkan permalasahan.

\section{Simpulan}

Berdasarkan kajian kepustakaan disimpulkan bahwa pelaksaan kebijaka merupakan upaya yang dilakukan dalam melaksanakan kebijakan dalam pencapaian tujuan. Pada pelaksaan kebijakan di pengaruhi oleh disposisi, sumber data, komunikasi dan struktur birokrasi yang berkaitan satu sama lainnya. Selain itu dalam proses pelaksanan kebijakan harus memperhatikan dimensi-dimensi yang berpengaruh terhadap kebijakan tersebut. Proses pelaksanaan kebijakan harus dievaluasi agar tercapainya tujuan yang telah ditetapkan.

\section{Referensi}

Afandi, M. I., \& Warjio, W. (2015). Implementasi Peraturan Daerah Kabupaten Asahan Nomor 11 Tahun 2011 Tentang Pajak Daerah Dalam Pencapaian Target Pajak Bumi Dan Bangunan Perdesaan Dan Perkotaan (Studi Deskriptif Di Kelurahan Bunut Barat Kecamatan Kota Kisaran Barat). Jurnal Administrasi Publik: Public Administration Journal, 5(2), 132-153.

Alam, A. S. (2012). Analisis kebijakan publik kebijakan sosial di perkotaan sebagai sebuah kajian implementatif. Jurnal Ilmiah Ilmu Pemerintahan, 1(3), 78-92.

Coryanata, I. (2011). Akuntabilitas, partisipasi masyarakat dan transparansi kebijakan publik sebagai pemoderasi hubungan pengetahuan dewan tentang anggaran dan pengawasan keuangan daerah. Journal of Accounting and Investment, 12(2), 110-125.

Fahri, L. N. (2017). Pengaruh Pelaksanaan Kebijakan Dana Desa terhadap Manajemen Keuangan Desa dalam Meningkatkan Efektivitas Program Pembangunan Desa. Jurnal Publik: Jurnal Ilmiah Bidang Ilmu Administrasi Negara, 11(1), 75-88.

Hanafi, I., \& Ma'sum, M. (2015). Analisis Implementasi Kebijakan Pendidikan: Peran Komite Sekolah Pada Sekolah Menengah Kejuruan. Jurnal Cakrawala Pendidikan, 34(1),1-10.

Hardiyansyah, H. (2018). Kualitas Pelayanan Publik: Konsep, Dimensi, Indikator dan Implementasinya. Jurnal Sosial dan Humaniora, 3(1), 39-45.

Herdiana, D. (2018). Sosialisasi Kebijakan Publik: Pengertian dan Konsep Dasar. Jurnal Ilmiah Wawasan Insan Akademik, 1(3), 13-26.

Iskandar, J. (2012). Kapita Selekta teori Administrasi Negara. Idaarah: Jurnal Manajemen Pendidikan, 1(2), 1-10.

Juliastuti, A. (2013). Pengaruh akuntabilitas publik, partisipasi masyarakat dan transparansi kebijakan publik terhadap hubungan pengetahuan Dewan tentang Anggaran dengan pengawasan keuangan Daerah. Jurnal Akuntansi, 1(1), 1-10.

Kartini, W. (2017). Pengaruh pelaksanaan kebijakan tentang puskesmas dan dukungan sarana prasarana terhadap manajemen pelayanan kesehatan untuk meningkatkan produktivitas kerja. Jurnal Publik: Jurnal Ilmiah Bidang Ilmu Administrasi Negara, 11(2), 146-156.

Kawengian, D. D., \& Rares, J. J. (2015). Evaluasi Kebijakan Pencegahan dan Pemberantasan Perdagangan Manusia (Trafficking) Terutama Perempuan dan Anak di Kabupaten Minahasa Selatan Provinsi Sulawesi Utara. Acta Diurna Komunikasi, 4(5),1-10

Mutiasari, M., Yamin, M. N., \& Alam, S. (2016). Implementasi Kebijakan Perizinan Dan Pemberitahuan Kegiatan Masyarakat Pada Kepolisian Resort (Polres) Kota Kendari. Publica: Jurnal Administrasi Pembangunan dan Kebijakan Publik, 7(1), 1-10.

Pratistha, B., \& Triharjanto, R. H. (2020). Evaluasi On Going Rencana Induk Penyelenggaraan Keantariksaan Tahun 2016-2040. Jurnal Kajian Kebijakan Penerbangan dan Antariksa, 1(1), 36-49.Budiani, R., \& Suliyati, T. (2016). Analisis Kegiatan Evaluasi Layanan Informasi Publik oleh Komisi Informasi Jawa Tengah Tahun 2013-2015. Jurnal Ilmu Perpustakaan, 5(3), 71-80. 
Ramdhani, A., \& Ramdhani, M. A. (2017). Konsep umum pelaksanaan kebijakan publik. Jurnal Publik, 11(1), $1-12$.

Retnaningsih, H. (2015). Permasalahan corporate social responsibility (csr) dalam rangka pemberdayaan masyarakat. Aspirasi: Jurnal Masalah-Masalah Sosial, 6(2), 177-188.

Ruhimat, I. S. (2010). Implementasi kebijakan kesatuan pengelolaan hutan (KPH) di Kabupaten Banjar. Jurnal Analisis Kebijakan Kehutanan, 7(3), 169-178.

Safira, M. E. (2018). Pembuatan Peraturan Daerah berdasarkan Undang-Undang nomor 23 tahun 2014 dalam sistem pembuatan perundangan-undangan menurut Undang-Undang nomor 12 tahun 2011 perspektif Fiqh Siyasah Dusturiyah (Doctoral dissertation, UIN Sunan Ampel Surabaya).

Sirajuddin, I. A. (2016). Implementasi Kebijakan Pemerintah Daerah Dalam Pelayanan Publik Dasar Bidang Sosial Di Kota Makassar. Jurnal Ilmiah Ilmu Administrasi Publik, 4(1), 1-14.

Subekti, M., Faozanudin, M., \& Rokhman, A. (2017). Pengaruh komunikasi, sumber daya, disposisi dan struktur birokrasi terhadap efektifitas implementasi program bantuan operasional sekolah pada satuan pendidikan Sekolah Dasar Negeri di Kecamatan Tambak. The Indonesian Journal of Public Administration (IJPA), 3(2), 58-71.

Sururi, A. (2016). Inovasi Kebijakan Publik (Tinjauan Konseptual dan Empiris). Sawala: Jurnal Administrasi Negara, 4(3), 1-10.

Suryono, A. (2014). Kebijakan publik untuk kesejahteraan rakyat. Transparansi: Jurnal Ilmiah Ilmu Administrasi, 6(2), 98-102.

Syani, A. K., Mufid, S., \& Hazin, M. (2018). Komunikasi dalam Implementasi Kebijakan Pendidikan Wajib Belajar 9 Tahun di Kecamatan Ngadiluwih. Khazanah Pendidikan, 11(1), 1-10

Wirawan, R., \& Nurpratiwi, R. (2015). Partisipasi masyarakat dalam perencanaan pembangunan daerah. JISIP: Jurnal Ilmu Sosial Dan Ilmu Politik, 4(2), 1-10 